\title{
BETA-SITOSTEROL AND ITS ANTINOCICEPTIVE MECHANISM ACTION
}

\author{
BETA-SITOSTEROL VE ANTINOSISEPTIF ETKI MEKANIZMASI
}

\author{
Ayşe Arzu ŞAKUL ${ }^{1}$ (D), Mehmet Evren OKUR ${ }^{2 *}$ \\ ${ }^{1}$ Istanbul Medipol University, School of Medicine, Department of Medical Pharmacology, 34810, \\ Istanbul, Turkey \\ ${ }^{2}$ University of Health Sciences, Faculty of Pharmacy, Department of Pharmacology, 34668, \\ Istanbul, Turkey
}

\begin{abstract}
Objective: In this study, the possible central antinociceptive activity of beta-sitosterol is investigated along with its association of stimulation of opioidergic, serotonergic, adrenergic, and cholinergic receptors to mice central analgesia because of the beta-sitosterol administration.

Material and Method: The beta-sitosterol was administrated to mice in various doses, such as 5, 10 and $20 \mathrm{mg} / \mathrm{kg}$. Then, the mice analyzed via hot-plate and tail-flick assay to investigate the possible antinociceptive effects of beta-sitosterol. Additionally, in order to associate the mechanism of action mechanism, $20 \mathrm{mg} / \mathrm{kg}$ of beta-sitosterol was intraperitoneally administered to the animal which were previously pre-treated with opioid antagonist naloxone $(5 \mathrm{mg} / \mathrm{kg})$, serotonin $5-\mathrm{HT}_{2 \mathrm{~A} / 2 \mathrm{C}}$ receptor antagonist ketanserin $(1 \mathrm{mg} / \mathrm{kg})$, serotonin $5-\mathrm{HT}_{3}$ receptor antagonist - ondansetron (1 mg/kg), $\alpha_{2}$-adrenoceptor antagonist yohimbine (1 $\left.\mathrm{mg} / \mathrm{kg}\right)$ and muscarinic antagonist atropine (5 $\mathrm{mg} / \mathrm{kg})$, as well as nicotinic antagonist mecamylamine (1 mg/kg).

Result and Discussion: The antinociceptive effect of beta-sitosterol was confirmed as dose-dependent for 5,10 , and $20 \mathrm{mg} / \mathrm{kg}$ doses in tail-flick and hot-plate tests. It can be concluded that beta-sitosterol promotes central antinociception effects associated with the spinal and supraspinal mediated cholinergic and opioidergic modulation.
\end{abstract}

Keywords: Antinociception, beta-sitosterol, cholinergic receptors, opioidergic receptors

ÖZ

Amaç: Bu çalışmada, farelerde beta-sitosterol uygulamasına bağlı santral analjezide opioiderjik, serotonerjik, adrenerjik ve kolinerjik reseptörleri ile ilişkili olası antinosiseptif aktivitesi araştırılmıştır.

\footnotetext{
* Corresponding Author/Sorumlu Yazar: Mehmet Evren Okur e-mail / e-posta: evrenokurecz@gmail.com, Phone / Tel.: +902164189616
} 
Gereç ve Yöntem: Beta-sitosterol, farelere 5, 10 ve $20 \mathrm{mg} / \mathrm{kg}$ dozlarinda uyguland. Daha sonra, fareler beta-sitosterolün olası antinosiseptif etkilerini araş̧tırmak için tail-flick ve hot-plate testleri ile analiz edildi. Ek

olarak, etki mekanizmasını değerlendirmek için, farelere, beta-sitosterol (20 mg/kg, intraperitonel) uygulamasindan önce opioid antagonisti nalokson (5 mg/kg), serotonin 5-HT3 reseptör antagonisti ondansetron $(1 \mathrm{mg} / \mathrm{kg})$, serotonin $5-\mathrm{HT}_{2 \mathrm{~A} / 2 \mathrm{C}}$ reseptör antagonisti ketanserin $(1 \mathrm{mg} / \mathrm{kg}), \alpha_{2}$-adrenoseptör antagonisti yohimbin $(1 \mathrm{mg} / \mathrm{kg})$ ve muskarinik antagonist atropin $(5 \mathrm{mg} / \mathrm{kg})$ ve ayrica nikotinik antagonisti mekamilamin $(1 \mathrm{mg} / \mathrm{kg})$ uygulandl.

Sonuç ve Tartışma: Beta-sitosterolün doza-bağll antinosiseptif etkisi, tail-flick ve hot-plate testlerinde 5, 10 ve $20 \mathrm{mg} / \mathrm{kg}$ dozlarında tespit edilmiştir. Beta-sitosterolün, spinal ve supraspinal aracıl kolinerjik ve opioiderjik modülasyon ile ilişkili merkezi antinosisepsiyon etkilerini teşvik ettiği sonucuna varllabilir.

Anahtar Kelimeler: Antinosisepsiyon, beta-sitosterol, kolinerjik reseptörler, opioiderjik reseptörler

\section{INTRODUCTION}

Last years, various management techniques of pain have been arisen in order to offer patients life quality. Such strategies include pharmacological approaches using pain relief medications, physical therapy, complementary therapies as meditation etc. The diagnosis of pain and the recognition of analgesia methods and pain management are very significant for both clinicians and emergency department doctors [1]. There are 4 categories of pain such as acute, nociceptive, chronic, and neuropathic. Nociceptive pain arouse from the neural pathways activity due to actual tissue damage or possible tissue-damaging stimuli [2]. Nociceptors receptors could be activated from acute noxious stimuli i.e. heat or cold temperatures, mechanical force, or chemical stimulation [3-5]. Thus, pharmacological agents presenting with antinociceptive properties are of high clinical importance. The application of pharmacological compounds derived from plants, is widely tested in clinical practice.

Beta-sitosterol (BS) is a chemical compound (Figure 1) widely found in plants such as Uncaria species (tomentosa, guianensis) [6,7] and vegetables i.e. rice [8], wheat [9], seeds and nuts [10] etc. BS has shown interesting curative properties such as anti-inflammatory, anti-viral, anti-cancer as well as immune boost [11-13]. The chemical structure of BS has been correlated with the structure of cholesterol; therefore, Tapiero et al. has reported that BS interferes with absorption of cholesterol in the intestines, and prevents cholesterol levels from being arisen in serum. Additionally, tumor growth inhibition by BS has been related with the effect of the sterol on sphingomyelin cycle and increased production of ceramide [14]. Other studies have included the antibacterial activity of BS [15] as well as its gastro- and hepatic-protective effects [16].

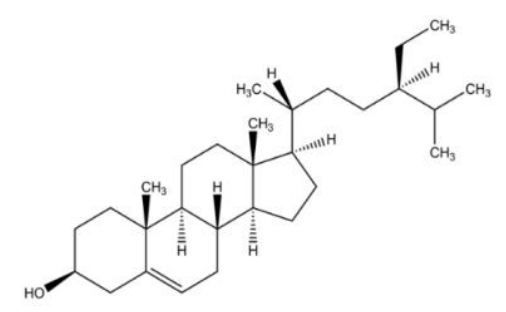

Figure 1. Chemical Structure of beta-sitosterol 
Most importantly, BS is reported to modulate immune function, inflammation [17], and pain levels through the production of inflammatory cytokines [18]. In general, the biological properties of BS have not been widely explored. In this study, the exploration of BS as pharmacological compound with antinociceptive properties is performed; mice models were administered with BS and studied for their behavior with the hot-plate and tail-flick assays.

\section{MATERIAL AND METHOD}

\section{Chemicals and Materials}

Beta-sitosterol, tween 80, yohimbine hydrochloride, diclofenac sodium, ketanserin tartrate, mecamylamine hydrochloride, naloxone hydrochloride, atropine sulfate, and ondansetron were purchased from Sigma, Germany. Herein, the used chemical components or solvents are of analytical grade. If they are not, they are stated accordingly.

\section{Animals}

Male Balb/C mice (20-25 g) were applied as animal models. The animals were kept at İstanbul Medipol University, in a room with controlled temperature $\left(22 \pm 2^{\circ} \mathrm{C}\right)$ and humidity $(55-70 \%)$ at $12 \mathrm{~h}$ light/dark cycles. Poly(propylene) boxes were used to maintain the mice containing wood shavings at the base of the box; the animals had free access to food and filtered water. Moreover, animals spread equally among the groups. Two hours before starting the experiments, the mice permitted to acclimatize to the air-conditioned. This was taken place during the light cycle phase. The experiment performed between 8.00 and 12.00 a.m. and the animals only intake water during the six hours prior to the experimental procedures. This choice based on the assumption that animals can present food interactions with BS. The animal care conditions as well as research protocols were chosen according to the principles and guidelines from the National Institute of Health Guide for the Care and Use of Laboratory Animals. The protocol confirmed by the Ethical Committee of İstanbul Medipol University (2020/69).

\section{Drugs and pharmacological procedures}

The animals were randomly allocated to 19 groups ( $\mathrm{n}=6$ per group). Beta-sitosterol and diclofenac were dissolved in the vehicle. Diclofenac $(5 \mathrm{mg} / \mathrm{kg}$, i.p.) was administrated as the reference drug. In further, BS was also i.p. administered (1\% Tween 80 in distilled water) at the doses of 5, 10, and $20 \mathrm{mg} / \mathrm{kg}$. Moreover, intraperitoneal injections of the antagonists were chosen. The action mechanisms were investigated by pre-treating the mice with muscarinic receptor antagonist; Atropine $(5 \mathrm{mg} / \mathrm{kg})$, nicotinic receptor antagonist; Mecamylamine $(1 \mathrm{mg} / \mathrm{kg})$, serotonin $5-\mathrm{HT}_{2 \mathrm{~A} / 2 \mathrm{C}}$ receptor antagonist; Ketanserin $(1 \mathrm{mg} / \mathrm{kg})$, serotonin $5-\mathrm{HT}_{3}$ receptor antagonist; Ondansetron $(1 \mathrm{mg} / \mathrm{kg})$, opioid antagonist; Naloxone $\left(1 \mathrm{mg} / \mathrm{kg}\right.$ ), and $\alpha_{2}$-adrenoceptor antagonist; Yohimbine $(1 \mathrm{mg} / \mathrm{kg})$ at 20, 30, 30, 30 and 15 min before the administration of BS, respectively. Before any combination studies were conducted, the antinociceptive effect of the antagonist agents when administered alone was examined 
in the mouse hot-plate and tail-flick assay. Hot-plate and tail-flick tests (90 min after BS administration) were performed in order to measure the pain threshold. The dosages and drug administration schedules were chosen according to previous reports [19-21].

\section{Pharmacological tests}

\section{Hot-plate test}

A hot-plate test was applied in order to examine the antinociceptive effect of BS. The choice of animals for the hot-plate test was based on their response time of up to $15 \mathrm{~s}$ such as to thermal stress. The animal selection was done the previous day of the experiment. A hot-plate analgesia meter was utilized to measure the pain reflexes in response to thermal stimuli (Ugo Basile Instruments, Comerio, Italy). The mice from each party were put on the pre-heated plate $\left(55 \pm 0.5^{\circ} \mathrm{C}\right)$. As reaction time was taken, the latency of licking or flicking of its hind paw or jumping upward. The $20 \mathrm{~s}$ were chosen as cutoff time in order to minimize hind paw damage. Finally, the mice behavior was recorded before treatment and after treatment [20].

\section{Tail-flick test}

The tail-flick latency was obtained using a tail-flick unit (Ugo Basile, Italy). Every animal settled to a certain way in order to tails project towards the nichrome wire. Moreover, the distal part of the tail (almost 2-3 cm lower portion of the tail) positioned upon the nichrome wire through which current flow set at 6 amp. The stimulus in this assay, was the radiant heat while the "tail-flick" response as well as "endpoint" was the immediate withdrawal of tail. In further, as "reaction time" was considered the time between placing the tail on heat and immediate removal of the tail. Additionally, the assay terminated if the latency exceeded for more than $15 \mathrm{~s}$ (cut-off time).

The later formula was applied in order to calculate maximal possible effect (MPE\%) according to the results obtained by the hot-plate and tail-flick assays $[22,23]$. The maximal possible effect percentage ascertained by the response latency against thermal stimulus:

MPE\% $=[\{($ Post-drug latency $)-($ Pre-drug latency $)\} /\{($ Cut-off time $)-($ Pre-drug latency $)\}]$ X100

\section{Statistical analysis}

The statistical analyses were performed with GraphPad Prism 7.0 software, Inc., San Diego, CA. The obtained data expressed as mean \pm SEM. Finally, the statistical analysis of the data was performed via one-way ANOVA which was followed by post hoc (Tukey's) analysis. As statistical significant, the $\mathrm{p}<0.05$ was chosen.

\section{RESULT AND DISCUSSION}

\section{Antinociceptive effect of beta-sitosterol}


Figure 2 presents the antinociceptive effects of BS according to hot-plate and tail-flick assays. Accordingly, it can be seen that diclofenac used as the reference drug, significantly hindered the pain response in comparison with the control group. This significant inhibition of pain response was recorded for both hot-plate $(\mathrm{p}<0.001)$ and tail-flick $(\mathrm{p}<0.001)$ tests. Moreover, the application of BS at doses of $20 \mathrm{mg} / \mathrm{kg}(\mathrm{p}<0.05)$ induced a notable as well as a dose-dependent increment in the mean basal reaction time in hot-plate and tail-flick tests, in comparison with the control group. Consequently, the obtained data clearly demonstrated that administration of $20 \mathrm{mg} / \mathrm{kg}$ of BS was remarkably more efficacious than the application of lower doses $(5,10 \mathrm{mg} / \mathrm{kg})$ of BS and the control group as well.
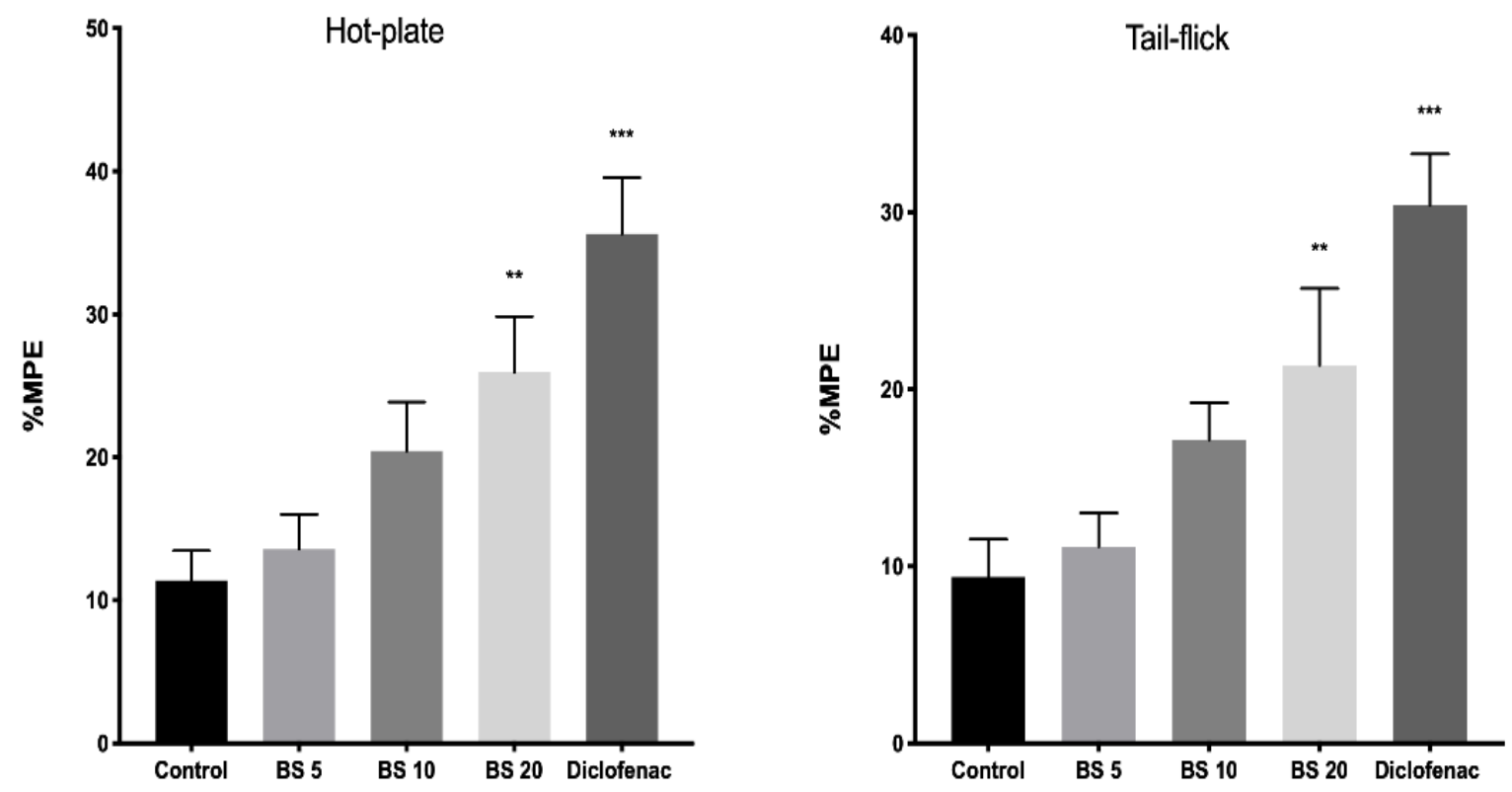

Figure 2. Antinociceptive effects of 5,10 , and $20 \mathrm{mg} / \mathrm{kg}$ (i.p.) beta-sitosterol (BS) and $5 \mathrm{mg} / \mathrm{kg}$ diclofenac (i.p.) in the hot-plate (hind paw withdrawal, licking or jumping) and tail-flick assays. Statistically significant difference; ${ }^{* *} \mathrm{p}<0.01,{ }^{* * *} \mathrm{p}<0.001$ vs. control. Data are shown as mean \pm S.E.M. MPE: Maximal possible antinociceptive effect.

\section{Evaluation of the mechanism of antinociceptive activity of Beta-sitosterol}

Figure 3 reveals the reversal effect of atropin on antinociception induced by BS $(20 \mathrm{mg} / \mathrm{kg})$. Pre-treatment with atropin caused the reverse of the pain relief effects of the BS in the hot-plate $(\mathrm{p}<0.001)$ and the tail-flick $(\mathrm{p}<0.001)$ assays. 

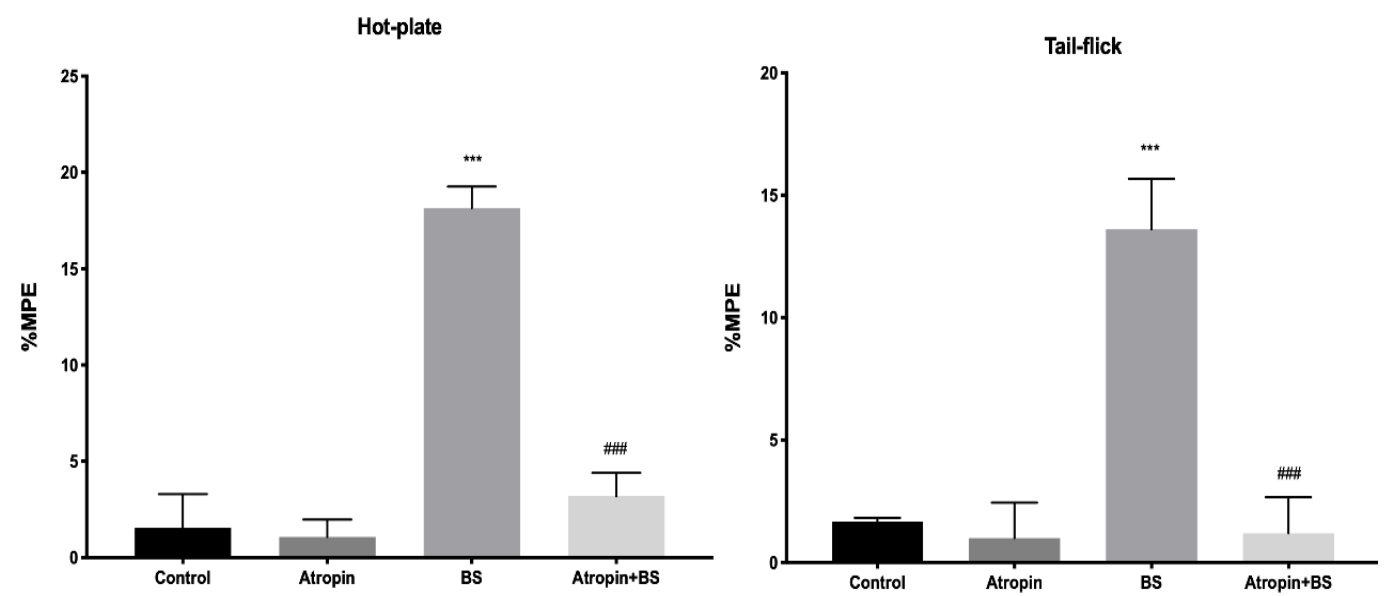

Figure 3. Effects of atropine (i.p. $-5 \mathrm{mg} / \mathrm{kg}$ ) on the antinociception of beta-sitosterol (BS) (i.p.-20mg/kg) in the hot-plate (hind paw withdrawal, licking or jumping) and tail-flick assays. Statistically significant difference, ${ }^{* * *} \mathrm{p}<0.001$ vs. control; ${ }^{\# \#} \mathrm{p}<0.001$ vs. beta-sitosterol alone. Data are shown as mean \pm S.E.M. MPE: Maximal possible antinociceptive effect.

As it can be seen from Figure 4, the single administration of mecamylamine ( $1 \mathrm{mg} / \mathrm{kg}$, i.p.) failed to show significance compared to the control group. Importantly, intraperitoneal pre-treatment with $1 \mathrm{mg} / \mathrm{kg}$ mecamylamine significantly reversed the antinociceptive action of BS $(20 \mathrm{mg} / \mathrm{kg})$ in the hot-plate $(\mathrm{p}<0.001)$ and tail-flick $(\mathrm{p}<0.001)$ tests in comparison with the BS alone.
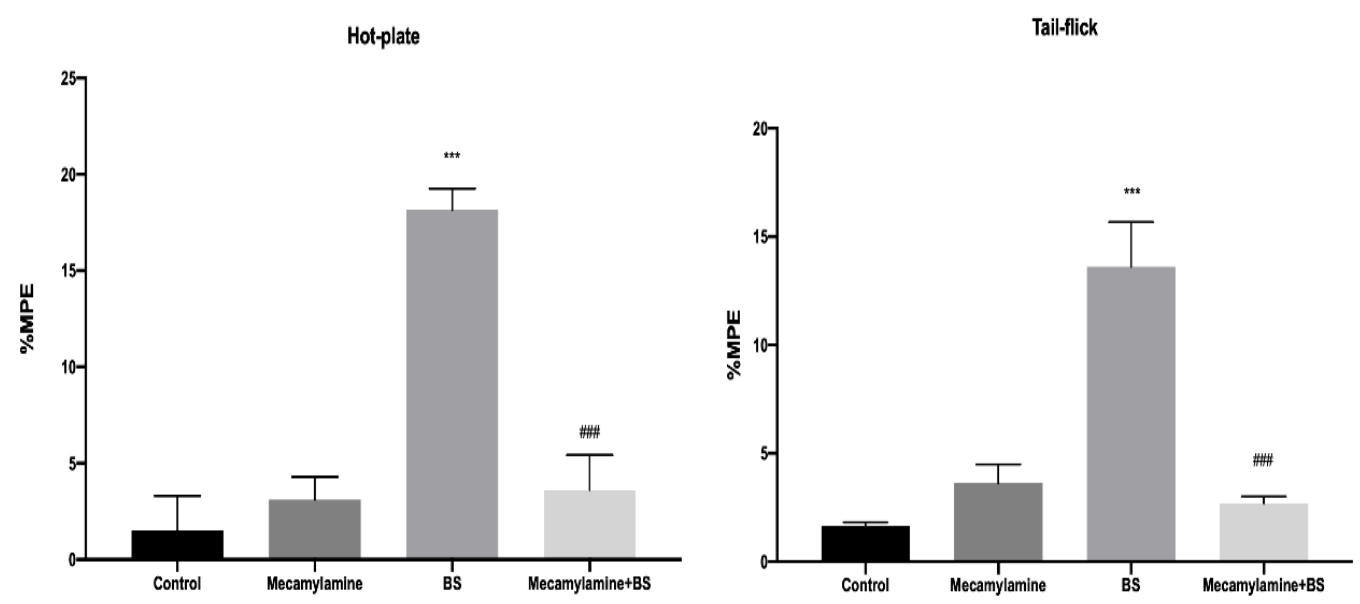

Figure 4. Effects of mecamylamine (i.p. $-1 \mathrm{mg} / \mathrm{kg}$ ) on the antinociception of beta-sitosterol (BS) (i.p.$20 \mathrm{mg} / \mathrm{kg}$ ) in the hot-plate (hind paw withdrawal, licking or jumping) and tail-flick assays. Statistically significant difference; ${ }^{* * *} \mathrm{p}<0.001$ vs. control; ${ }^{\# \#} \mathrm{p}<0.001$ vs. beta-sitosterol alone. Data are shown as mean \pm S.E.M. MPE: Maximal possible antinociceptive effect. 
The effect of ketanserin treatment on tail-flick and hot-plate tests was intended to be clarified via the single administration of ketanserin $(1 \mathrm{mg} / \mathrm{kg})$; nonetheless, the administration did not cause any significant difference in antinociceptive response (Figure 5). The results indicate that ketanserin also did not reverse the antinociceptive effect observed for BS in a significant way.
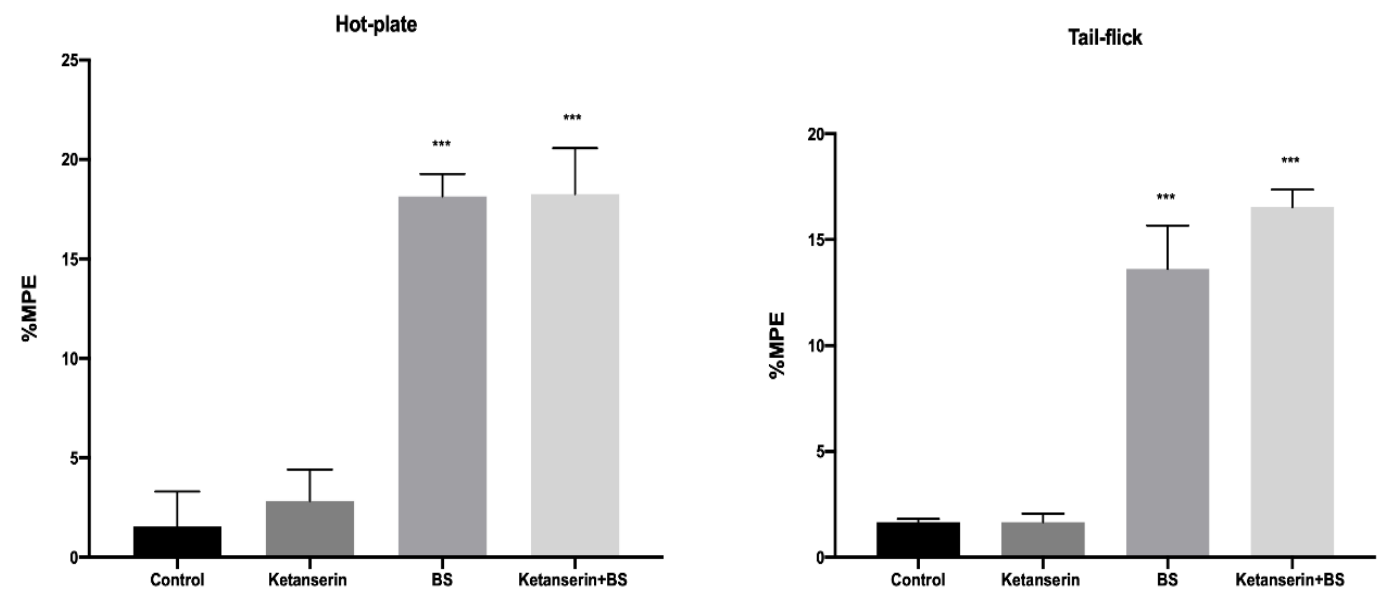

Figure 5. Effects of ketanserin (i.p. $-1 \mathrm{mg} / \mathrm{kg}$ ) on the antinociception of beta-sitosterol (BS) (i.p.$20 \mathrm{mg} / \mathrm{kg}$ ) in the hot-plate (hind paw withdrawal, licking or jumping) and tail-flick assays. Statistically significant difference; ${ }^{* * *} \mathrm{p}<0.001$ vs. control. Data are shown as mean \pm S.E.M. MPE: Maximal possible antinociceptive effect.

Hot-plate

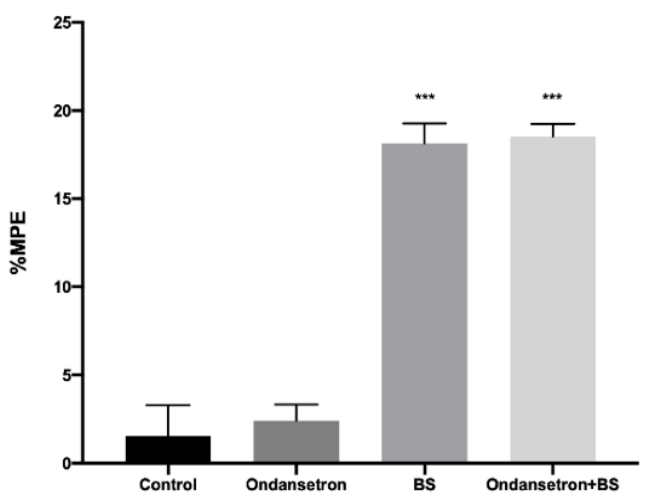

Tail-flick

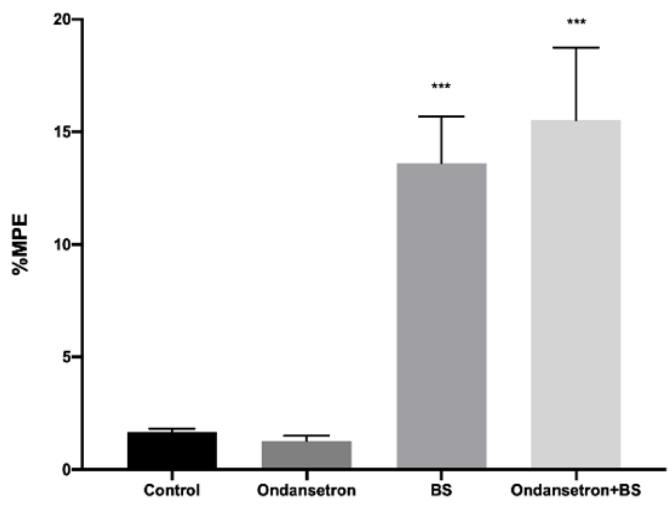

Figure 6. Effects of ondansetron (i.p. $-5 \mathrm{mg} / \mathrm{kg}$ ) on the antinociception of beta-sitosterol (BS) (i.p.$20 \mathrm{mg} / \mathrm{kg}$ ) in the hot-plate (hind paw withdrawal, licking or jumping) and tail-flick assays. Statistically significant difference; ${ }^{* * *} \mathrm{p}<0.001$ vs. control. Data are shown as mean \pm S.E.M. MPE: Maximal possible antinociceptive effect. 
As depicted in Figure 6, the administration of intraperitoneal injection of $5 \mathrm{mg} / \mathrm{kg}$ ondansetron did not modify the antinociceptive activity of BA $(20 \mathrm{mg} / \mathrm{kg})$ in the hot-plate and tail-flick assays. Moreover, ondansetron pre-treatment did not significantly decrease in latency of the BA-mediated analgesic responses according to the hot-plate and tail-flick procedures.
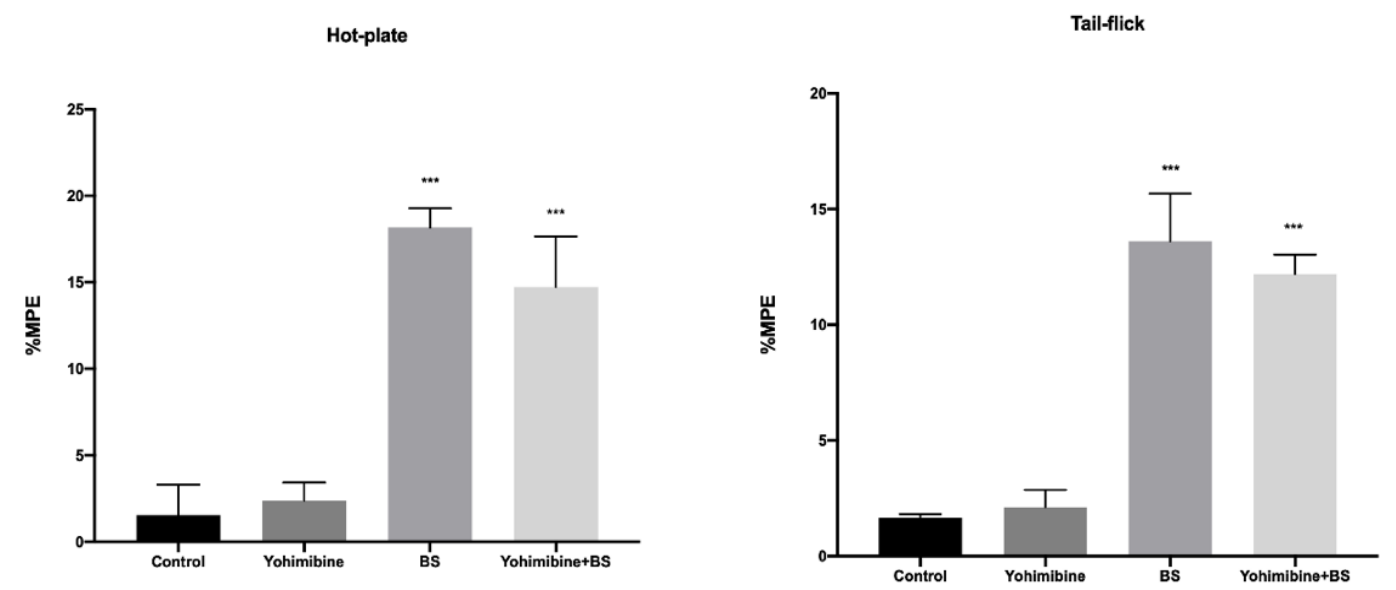

Figure 7. Effects of yohimbine (i.p.- $1 \mathrm{mg} / \mathrm{kg}$ ) on the antinociception of beta-sitosterol (BS) (i.p.$20 \mathrm{mg} / \mathrm{kg}$ ) in the hot-plate (hind paw withdrawal, licking or jumping) and tail-flick assays. Statistically significant difference; ${ }^{* * *} \mathrm{p}<0.001$ vs. control. Data are shown as mean \pm S.E.M. MPE: Maximal possible antinociceptive effect.
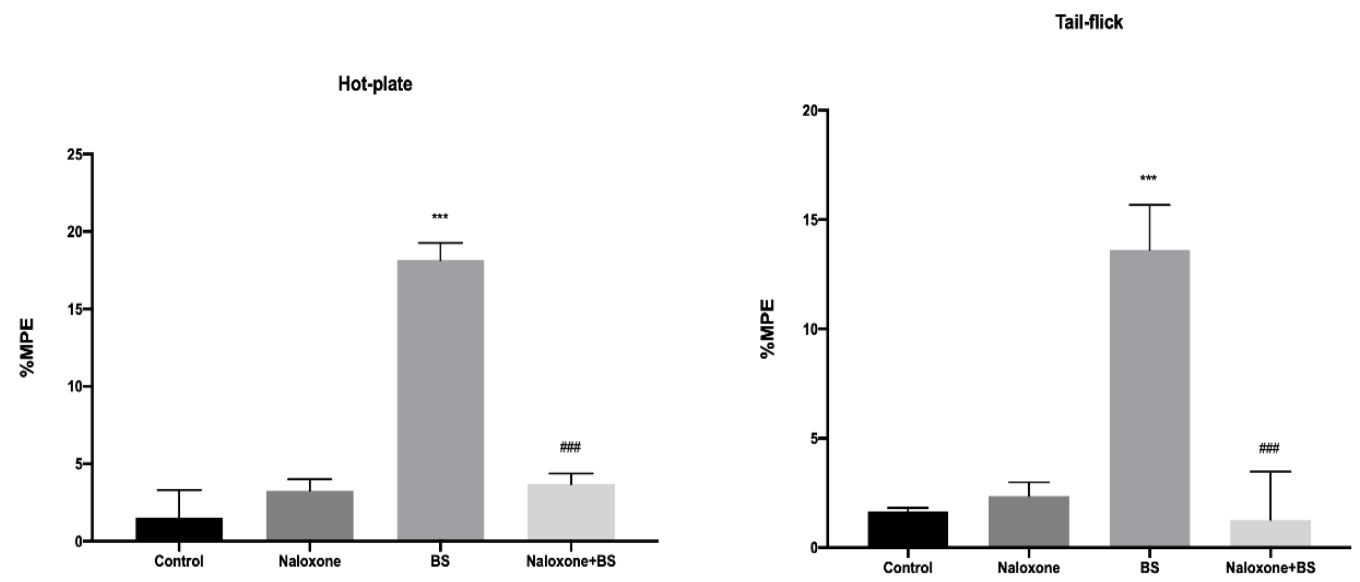

Figure 8. Effects of naloxone (i.p.-5mg/kg) on the antinociception of beta-sitosterol (BS) (i.p.-20mg/kg) in the hot-plate (hind paw withdrawal, licking or jumping) and tail-flick assays. Statistically significant difference, ${ }^{* * *} \mathrm{p}<0.001$ vs. control; ${ }^{\# \#} \mathrm{p}<0.001$ vs. beta-sitosterol alone. Data are shown as mean \pm S.E.M. MPE: Maximal possible antinociceptive effect. 
Figure 7 shows that pre-treatment with only yohimbine $(1 \mathrm{mg} / \mathrm{kg}$, i.p.) have not employed any antinociceptive effect in both hot-plate and tail-flick tests. Moreover, the pre-treatment with yohimbine have not reduced the BS-induced acute thermal antinociceptive effect according to the data obtained by the hot-plate or tail-flick tests.

Figure 8 depicts the involvement of opioid receptors in the antinociceptive effects of BS assessed using hot-plate and tail-flick tests, respectively. The treatment of mice with naloxone $(5 \mathrm{mg} / \mathrm{kg}$, i.p.) have not significantly altered the latency response in the hot-plate and tail-flick assays. On the other hand, the pre-treatment with the non-selective opioid antagonist, naloxone, importantly blocked BSinduced antinociception in the hot-plate $(\mathrm{p}<0.001)$ and tail-flick $(\mathrm{p}<0.001)$ tests in comparison with BS alone.

Phytosterol phytocompounds such as BS present a similar structure to cholesterol. BS can be characterized as one of the common and major phytosterol with numerous biological activities. Consequently, BS is a drastic pharmacological agent with protective activities against chronic disorders, oxidative stress, and neoplasm [24]. Besides, various scientific data derived from reports report that BS present anti-diabetic, anti-inflammatory, chemopreventive and anticancer properties [25]. Nevertheless, the investigation on the effect of BS at molecular level remains unclear. The present study demonstrates that $\mathrm{BS}$ at $20 \mathrm{mg} / \mathrm{kg}$ (i.p.) displays anti-nociceptive activity, whereas the obtained data might evidence the implicated mechanisms of that activity.

Herein, the antinociceptive effect of BS was examined via two known methodologies involving stimuli. The two methods, hot-plate and tail-flick assays involve the thermal stimuli which stimulate the A $\delta$ fibers. Nonetheless, both of tests note different neural pathways. More specifically, the tail-flick is a spinal reflex [26]. On the other hand, the hot-plate response is under supraspinal control given that the hot-plate assay is a specific centrally antinociceptive activity assay [19]. According to Wang et al., the hot-plate assay considered to engange in supraspinal sites since only the administration of central analgesics enlarge the response time during the experimental [27].

Dighe et al. previously reported that BS $(5,10$ and $20 \mathrm{mg} / \mathrm{kg}$, i.p.) isolated from leaves of Oxalis corniculata, displayed promising dose-dependent central-mediated analgesic activity in rodents, according to the data obtained by hot plate test and acetic acid-induced writhing test. The data compared to active drug, pentazocine [19]. Furthermore, Scapinello et al. demonstrated that various plant extracts including BS, stigmasterol, and the isolated components depicted antinociceptive effects in mice, according to stimuli responsive tests as formalin, writhing, and hot-plate [28]. Various pharmacological approaches have revealed that Cyclooxygenase (COX)-mediated peripheral nociceptive mechanisms contribute to pain [29]. Subsequently, data obtained via in vitro COX inhibition assay confirm the in vivo system via the acetic acid-mediated peripheral nociceptive pain remedy [30]. A past study revealed that BS isolated from Nyctanthes arbortristis leaves can provide protection against peripheral 
nociceptive pain in a dose dependent manner [31].The data are related with our study, given that as BS dose increased, antinociception also determined. Moreover, herein, the determination of the involved mechanism to the central antinociception caused by BS, was carried out by using numerous typical antagonists of serotonergic, noradrenergic, opioid, and cholinergic receptors.

It is known that muscarinic and nicotinic acetylcholine receptors mediate the integrative activity of acetylcholine in numerous brain functions as ascognition, attention, emotion, and synaptic plasticity. Moreover, recent data has recommended that the aforementioned receptors might involve in supraspinal pain modulation excepts the known local peripheral and spinal contributions in mediating pain [32]. Besides, muscarinic acetylcholine receptors are broadly categorized as pharmacologic targets for pain relief while the majority of those focused on central nervous system muscarinic acetylcholine receptors [33].

From the obtained data, cholinergic receptors are being involved in antinociception considering that atropine reversed the antinociception of BS. Spinal cord is a major action target for cholinomimetics in analgesia. It has been suggested that painful stimuli improve acetylcholine in the spinal cord. Therefore, the stimulation of muscarinic receptors in the spinal cord leads to a great discharge of inhibitory transmitters associated with reductions in the secretion of excitatory transmitters; this fact mediates their antinociception [34].

In further, it should be mentioned that the cholinergic system present plethora of therapeutic targeted sites against numerous clinically relevant pain states. Guginski et al. proposed that acetylcholine mediates its effects through both nicotinic acetylcholine receptors (ligand-gated ion channels) and the $\mathrm{G}$ protein-coupled muscarinic receptors [35]. It can be evidenced, that the cholinergic system involves into the antinociception caused by BS, according to the obtained results after mecamylamine administration at a dose similar to that known to prevent antinociception induced by nicotinic receptor agonist. Besides, a number of studies reported that $\alpha_{4} \beta_{2}$ ligands present antinociceptive effects in relevance with their action on spinal and supraspinal pathways. The $\alpha_{4} \beta_{2}$ receptors can be ascertained to various brain areas, including the nucleusraphe magnus, midbrain periaqueductal gray, and locus coeruleus [36].

In addition, the findings obtained have shown that the effects of the BS tend to include the involvement of the opioid system. It is reported that the opioids perform their analgesic activity through the spinal $\left(\mu_{2}, \mathrm{k}_{1}, \delta_{2}\right)$ receptors and supraspinal $\left(\mu_{1}, \mathrm{k}_{3}, \delta_{1}, \sigma_{2}\right)$ [19]. Naloxone is a specific opioid receptor antagonist in the central nervous system, able to restrict the effect of anesthetics, such as morphine [28]. Therefore, naloxone was applied in order to examine the opioid effect of BS and effect of naloxone on beta-sitosterol on thermic stimulus-induced pain involvement in the mechanism of antinociceptive action. BS was applied following naloxone $(1 \mathrm{mg} / \mathrm{kg}$, s.c.) administration according to previous report 
studying the involvement of opioid receptors. It was revealed that naloxone reversed its antinociceptive activity [19].

The noradrenergic receptor system seems to play a major role in nociception and antinociception in various species. The noradrenergic receptor system comprises the endogenous ligand nor-adrenaline and its receptors. It is reported that term "noradrenergic" mostly refers to alpha-, while adrenergic refers to beta-adrenergic receptors; although, nor-adrenaline can bind to $\beta$-adrenergic receptors. This fact is related to the lower binding affinity of noradrenaline to beta-adrenergic than alpha-adrenergic receptors [37]. According to this assumption, the term noradrenergic receptor system was chosen for this study. Noradrenergic receptor system is targeted by $\alpha_{2}$ adrenergic molecules such as clonidine, dexmedetomidine and xylazine which are agonists and antagonists such as yohimbine [38]. Consequently, in order to examine the involvement of antagonism in antinociception, a dose of $1 \mathrm{mg} / \mathrm{kg}$ yohimbine was administered. The chosen dose has not significantly affected the pain-related behavior of animals, according to control. When BS administered in $20 \mathrm{mg} / \mathrm{kg}$ dose, the application of yohimbine did not reverse the antinociceptive effect followed by BS dose.

Numerous studies have demonstrated that serotonin regulates nociceptive reaction by $5-\mathrm{HT}_{1}, 5-$ $\mathrm{HT}_{2}, 5-\mathrm{HT}_{3}$, and 5- $\mathrm{HT}_{7}$ receptors in the central nervous system [39]. Consequently, serotonin receptors might involve to nociceptive response. Moreover, pain perception can be altered via inhibitory descending ways from the central nervous system and especially serotonin. The inhibition of pain transmission can occur via the activation of descending ways from the raphe nuclei to the dorsal horn of spinal cord, mediated via serotonin. In case of peripheral level, serotonin might involve with pain signalization [40]. According to the results of hot-plate and tail-flick tests, ketanserin and ondansetron which are the selective antagonists of 5- $\mathrm{HT}_{2 \mathrm{~A} / 2 \mathrm{C}}$ and $5-\mathrm{HT}_{3}$ receptors, have not blocked the reduction in nociceptive response induced by BS ( $20 \mathrm{mg} / \mathrm{kg})$. Subsequently, the serotonergic system has not involved in the antinociceptive action of BS.

From the present study, involving the test of beta-sitosterol as antinociceptive agent according to hot-plate and tail-flick tests, it can be concluded that BS present an antinociceptive effect on nociception-induced tests. Although, future studies will allow determining the involved mechanisms, a contribution of the opioid and cholinergic systems in the antinociceptive action of beta-sitosterol can be ascertained. Finally, more studies would be able to exert the favorable role of beta-sitosterol to pain control and management.

\section{AUTHOR CONTRIBUTIONS}

Conception: A.A.Ş., M.E.O.; Design: A.A.Ş., M.E.O.; Supervision: A.A.Ş., M.E.O.; Resources: A.A.Ş., M.E.O.; Materials: A.A.Ş., M.E.O.; Data collection and/or processing: A.A.Ş., M.E.O.; Analysis 
and/or interpretation: A.A.Ş., M.E.O.; Literature search: A.A.Ş., M.E.O.; Writing manuscript: A.A.Ş., M.E.O.; Critical review: A.A.Ş., M.E.O.; Other: -

\section{CONFLICT OF INTEREST}

The authors declare no conflict of interest.

\section{ETHICS COMMITTEE APPROVAL}

The protocol confirmed by the Ethical Committee of İstanbul Medipol University (2020/69).

\section{REFERENCES}

1. Çarıkçı, A., Uçar, F., Yalçın, H. T. (2008). Kozmetik ürünlerde bakteriyal ve fungal kompozisyonun klasik yöntemler ve per yöntemi kullanılarak saptanması. Elektronik Mikrobiyoloji Dergisi, 6(01), 1-16.

2. Abdolrazaghnejad, A., Banaie, M., Tavakoli, N., Safdari, M., Rajabpour-Sanati, A. (2018). Pain management in the emergency department: a review article on options and methods. Advanced Journal of Emergency Medicine, 2(4), e45. doi: 10.22114/AJEM.v0i0.93.

3. Nicholson, B. (2006). Differential diagnosis: nociceptive and neuropathic pain. The American Journal of Managed Care, 12(9), 256-262.

4. Mitsi, V., Zachariou, V. (2016). Modulation of pain, nociception, and analgesia by the brain reward center. Neuroscience, 338, 81-92.

5. Falk, S., Dickenson, A.H. (2014). Pain and nociception: mechanisms of cancer-induced bone pain. Journal of Clinical Oncology, 32(16), 1647-1654.

6. Armstrong, S., Herr, M. (2020). Physiology, Nociception. In: StatPearls. Treasure Island (FL): StatPearls.

7. Prieto Rodríguez, J.A., Patiño Ladino, O.J., Lesmes, L., Lozano, J.M., Cuca Suárez, L.E. (2011). Phytochemical study of uncaria guianensis leaves and antibacterial activity evaluation. Acta Amazonica, 41(2), 303-310.

8. Yepes-Pérez, A.F., Herrera-Calderon, O., Sánchez-Aparicio, J.E., Tiessler-Sala, L., Maréchal, J.D., Cardona-G, W. (2020). Investigating potential inhibitory effect of uncaria tomentosa (cat's claw) against the main protease 3CLpro of SARS-CoV-2 by molecular modeling. EvidenceBased Complementary and Alternative Medicine, 2020, 4932572.

9. Vissers, M.N., Zock, P.L., Meijer, G.W., Katan, M.B. (2000). Effect of plant sterols from rice bran oil and triterpene alcohols from sheanut oil on serum lipoprotein concentrations in humans. The American Journal of Clinical Nutrition., 72(6), 1510-1515. 
10. Elkeilsh, A., Awad, Y.M., Soliman, M.H., Abu-Elsaoud, A., Abdelhamid, M.T., El-Metwally, I.M. (2019). Exogenous application of $\beta$-sitosterol mediated growth and yield improvement in water-stressed wheat (Triticum aestivum) involves up-regulated antioxidant system. Journal of Plant Research, 132(6), 881-901.

11. Delgado-Zammarreno, M.M., Bustamante-Rangel, M., Martinez-Pelarda, D., CarabiasMartinez, R. (2009). Analysis of beta-sitosterol in seeds and nuts using pressurized liquid extraction and liquid chromatography. Analytical Sciences, 25(6), 765-768.

12. Kim, S.-J. (2017). The ameliorative effect of $\beta$-sitosterol on DNCB-induced atopic dermatitis in mice. Biomedical Science Letters, 23(4), 303-309.

13. Saeidnia, S., Manayi, A., Gohari, A.R., Abdollahi, M. (2014). The story of beta-sitosterol- a review. European Journal of Medicinal Plants, 4(5), 590-609.

14. Heitzman, M., Neto, C.C., Winiarz, E., Vaisberg, A.J., Hammond, G.B. (2005). Ethnobotany, phytochemistry and pharmacology of (Rubiaceae). Phytochemistry, 66(1), 5-29.

15. Tapiero, H., Townsend, D.M., Tew, K.D. (2003). Phytosterols in the prevention of human pathologies. Biomedicine \& Pharmacotherapy, 57(8), 321-325.

16. Ododo, M.M., Choudhury, M.K., Dekebo, A.H. (2016). Structure elucidation of $\beta$-sitosterol with antibacterial activity from the root bark of Malva parviflora. Springerplus, 5(1), 1210.

17. Feng, S., Dai, Z., Liu, A.B., Huang, J., Narsipur, N., Guo, G., Guo, G., Kong, B., Reuhl, K., Lu, W., Luo, Z., Yang, C.S. (2018). Intake of stigmasterol and $\beta$-sitosterol alters lipid metabolism and alleviates NAFLD in mice fed a high-fat western-style diet. Biochimica et Biophysica Acta (BBA)-Molecular and Cell Biology of Lipids, 1863(10), 1274-1284.

18. Liu, R., Hao, D., Xu, W., Li, J., Li, X., Shen, D., Sheng, K., Zhao, L., Xu, W., Gao, Z., Zhao, X., Liu, Q., Zhang, Y. (2019). $\beta$-Sitosterol modulates macrophage polarization and attenuates rheumatoid inflammation in mice. Pharmaceutical Biology, 57(1), 161-168.

19. Paniagua-Pérez, R., Flores-Mondragón, G., Reyes-Legorreta, C., Herrera-López, B., CervantesHernández, I., Madrigal-Santillán, O., Morales-González, J.A.,Álvarez-González, I., MadrigalBujaidar, E. (2016). Evaluation of the anti-inflammatory capacity of beta-sitosterol in rodent assay. African Journal of Traditional, Complementary and Alternative Medicines, 14(1), 123 130.

20. Dighe, S. B., Kuchekar, B. S., Wankhede, S. B. (2019). Analgesic and anti-inflammatory activity of $\beta$-sitosterol isolated from leaves of Oxalis corniculata. International Journal of Pharmacological Research, 09(05), 109-113.

21. Arslan, R., Bektas, N. (2015). Evaluation of the centrally-acting mechanisms of some nonsteroidal anti-inflammatory drugs. American Journal of Pharmacy \& Health Research, 3(6), 191-202.

22. Arslan, R., Aydin, S., Nemutlu Samur, D., Bektas, N. (2018). The possible mechanisms of protocatechuic acid-induced central analgesia. Saudi Pharmaceutical Journal, 26(4), 541-545.

23. Majumder, R., Adhikari, L., Dhara, M., Sahu, J. (2020). Evaluation of anti-inflammatory, analgesic and TNF- $\alpha$ inhibition (upon RAW 264.7 cell line) followed by the selection of extract (leaf and stem) with respect to potency to introduce anti-oral-ulcer model obtained from Olax 
psittacorum (Lam.) Vahl in addition to GC-MS illustration. Journal of Ethnopharmacology, $263,113146$.

24. De Caro, C., Raucci, F., Saviano, A., Cristiano, C., Casillo, G. M., Di Lorenzo, R., Sacchi, A., Laneri, S., Dini, I., De Vita, S., Chini, M. G., Bifulco, G., Calignano, A., Maione, F., Mascolo, N. (2020). Pharmacological and molecular docking assessment of cryptotanshinone as naturalderived analgesic compound. Biomedicine \& Pharmacotherapy, 126, 110042.

25. Devaraj, E., Roy, A., Royapuram Veeraragavan, G., Magesh, A., Varikalam Sleeba, A., Arivarasu, L., Marimuthu Parasuraman, B. (2020). $\beta$-Sitosterol attenuates carbon tetrachlorideinduced oxidative stress and chronic liver injury in rats. Naunyn-Schmiedeberg's Archives of Pharmacology, 393(6), 1067-1075.

26. Babu, S., Krishnan, M., Rajagopal, P., Periyasamy, V., Veeraraghavan, V., Govindan, R., Jayaraman, S. (2020). Beta-sitosterol attenuates insulin resistance in adipose tissue via IRS1/Akt mediated insulin signaling in high fat diet and sucrose induced type-2 diabetic rats. European Journal of Pharmacology, 873, 173004.

27. Afify, E. A., Alkreathy, H. M., Ali, A.S., Alfaifi, H.A., Khan, L.M. (2017). Characterization of the antinociceptive mechanisms of khat extract (Catha edulis) in mice. Frontiers in Neurology, 8,69 .

28. Wang, Y., Su, D. M., Wang, R.H., Liu, Y., Wang, H. (2005). Antinociceptive effects of choline against acute and inflammatory pain. Neuroscience, 132(1), 49-56.

29. Scapinello, J., Müller, L. G., Schindler, M., Anzollin, G. S., Siebel, A. M., Boligon, A. A., Niero, R., Saraiva, T., Maus, N. P., Betti, A. H., Oliveira, J. V., Magro, J. D., \& de Oliveira, D. (2019). Antinociceptive and anti-inflammatory activities of Philodendron bipinnatifidum Schott ex Endl (Araceae). Journal of Ethnopharmacology, 236, 21-30.

30. Jang, Y., Kim, M., Hwang, S. W. (2020). Molecular mechanisms underlying the actions of arachidonic acid-derived prostaglandins on peripheral nociception. Journal of Neuroinflammation, 17(1), 30 .

31. Das, N., Bhattacharya, A., Kumar Mandal, S., Debnath, U., Dinda, B., Mandal, S. C., Kumar Sinhamahapatra, P., Kumar, A., Dutta Choudhury, M., Maiti, S., \& Palit, P. (2018). Ichnocarpus frutescens (L.) R. Br. root derived phyto-steroids defends inflammation and algesia by pulling down the pro-inflammatory and nociceptive pain mediators: An in-vitro and in-vivo appraisal. Steroids, 139, 18-27.

32. Nirmal, S. A., Pal, S. C., Mandal, S. C., Patil, A. N. (2012). Analgesic and anti-inflammatory activity of $\beta$-sitosterol isolated from Nyctanthes arbortristis leaves. Inflammopharmacology, 20(4), 219-224.

33. Tamaddonfard, E., Erfanparast, A., Abbas Farshid, A., Delkhosh-Kasmaie, F. (2017). Role of ventrolateral orbital cortex muscarinic and nicotinic receptors in modulation of capsaicininduced orofacial pain-related behaviors in rats. European Journal of Pharmacology, 815, 399404.

34. Zhao, X., Ye, J., Sun, Q., Xiong, Y., Li, R., Jiang, Y. (2011). Antinociceptive effect of spirocyclopiperazinium salt compound LXM-15 via activating peripheral $\alpha 7 \mathrm{nAChR}$ and M4 mAChR in mice. Neuropharmacology, 60(2-3), 446-452. 
35. Pinheiro, M.M.G., Boylan, F., Fernandes, P.D. (2012). Antinociceptive effect of the Orbignya speciosa Mart. (Babassu) leaves: Evidence for the involvement of apigenin. Life Sciences, 91(910), 293-300.

36. Guginski, G., Luiz, A.P., Silva, M.D., Massaro, M., Martins, D.F., Chaves, J., Mattos, R.W., Silveira, D., Ferreira, V.M.M. Calixto, J. B., Santos, A.R. (2009). Mechanisms involved in the antinociception caused by ethanolic extract obtained from the leaves of Melissa officinalis (lemon balm) in mice. Pharmacology Biochemistry and Behavior, 93(1), 10-16.

37. Li, W., Cai, J., Wang, B.H., Huang, L., Fan, J., Wang, Y. (2018). Antinociceptive effects of novel epibatidine analogs through activation of $\alpha 4 \beta 2$ nicotinic receptors. Science China Life Sciences, 61(6), 688-695.

38. Atzori, M., Cuevas-Olguin, R., Esquivel-Rendon, E., Garcia-Oscos, F., Salgado-Delgado, R. C., Saderi, N., Miranda-Morales, M., Treviño, M., Pineda, J. C., Salgado, H. (2016). Locus ceruleus norepinephrine release: A central regulator of cns spatio-temporal activation? Frontiers in Synaptic Neuroscience, 8, 25.

39. Mwobobia, R.M., Kanui, T.I., Abelson, K.S.P. (2020). Investigation of noradrenergic receptor system in anti-nociception using formalin test in the naked mole rat (Heterocephalus glaber). Heliyon, 6(10), e05216.

40. Cortes-Altamirano, J. L., Olmos-Hernandez, A., Jaime, H.B., Carrillo-Mora, P., Bandala, C., Reyes-Long, S., Alfaro-Rodríguez, A. (2018). Review: 5-HT1, 5-HT2, 5-HT3 and 5-HT7 receptors and their role in the modulation of pain response in the central nervous system. Current Neuropharmacology, 16(2), 210-221.

41. Anversa, R.G., Sousa, F.S.S., Birmann, P.T., Lima, D.B., Lenardão, E.J., Bruning, C.A., Savegnago, L. (2018). Antinociceptive and anti-inflammatory effects of 1,2-bis-(4 methoxyphenylselanyl) styrene in mice: involvement of the serotonergic system. Journal of Pharmacy and Pharmacology, 70(7), 901-909. 